\title{
Job satisfaction and performance of elementary school teachers
}

\author{
Agustinus Kia Wolomasi ${ }^{1}$, Sandra Ingried Asaloei ${ }^{2}$, Basilius Redan Werang ${ }^{3}$ \\ ${ }^{1}$ Sekolah Tinggi Katolik Santo Yakobus Merauke, Indonesia \\ ${ }^{2}$ Faculty of Administrative Sciences, Universitas Sam Ratulangi Manado, Indonesia \\ ${ }^{3}$ Faculty of Teacher Training and Education, Universitas Musamus Merauke, Indonesia
}

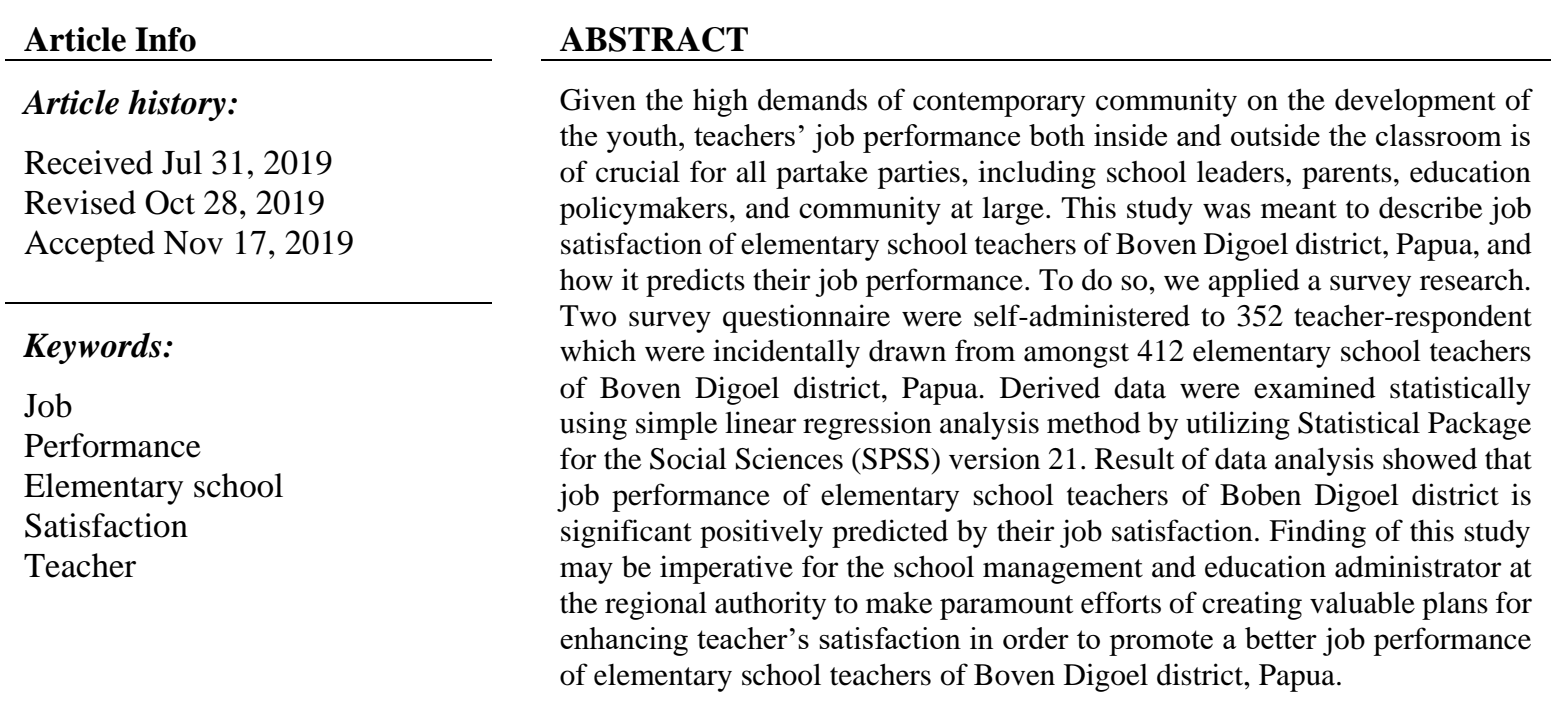

Copyright $(2019$ Institute of Advanced Engineering and Science. All rights reserved.

\section{Corresponding Author:}

Basilius Redan Werang,

Faculty of Teacher Training and Education,

Universitas Musamus Merauke,

Jalan Kamizaun, Mopah Lama, Merauke 99611, Papua, Indonesia.

Email: lirang267@yahoo.co.id

\section{INTRODUCTION}

Teaching is generally perceived as the most challenging job in contemporary society [1] as its professional are respected to be in charge for the academic achievement as well as social and emotional development of the youth [2]. For the youth of nations, teachers are expected to motivate them to study hard and to help them find a place in a contemporary society where they are able to fit in. Given the overwhelming demands of contemporary community on the growth of the youth, teachers' job performance both inside and outside the classroom is of crucial for all partake parties, including school leaders, parents, education policymakers, and community at large [3]. Teachers, therefore, from day to day, have to strive to meet the principles of effective teaching practice in order that the best learning experience is adequately provided.

Teaching-learning process is basically an interactions between different individuals that is carried within a social context where teacher and students roles are generally clearly defined. Teachers expect students to actively participate their class and students, in reverse, expect that teacher will influence their learning process into some significant extend. This expected condition does not really happen in the elementary schools of Boven Digoel district since teacher absenteeism rate is still high. High level of teacher absenteeism in elementary schools of Southern Papua as reported by Werang et al. [4] has not just affected classroom consistency and teachers-students interactions but also added-up students' capability in reading, writing, and arithmetic (3Rs) [5]. 
Teachers are role models for their respective students and, therefore, teachers' job performance is of crucial for students' success [6]. We do believe, elementary school students' incapability in 3Rs, in its very nature, has to be considered as related much to teachers' low performance. In this point of view, we feel the need for investigating the job performance of elementary school teachers of Boven Digoel district, Papua, with their satisfaction as predictor. Though researchers (e.g. [7-15]) have revealed various predicting factors for high-or-low level of job performance, we are encouraged to explore more this topic in order to address the following two issues: (a) high level of teacher absenteeism in the primary schools of Southern Papua, and (b) the primary school students' incapability in reading, writing, and arithmetic [4, 5]. Despite the similar ending of this study to the previous ones, finding of this investigation may hypothetically contributes to the current body of knowledge on the investigated area as it provides the first look on job satisfaction and performance of elementary school teachers in the context of Boven Digoel district, Papua.

The existing literature encompasses various studies on how teachers' job performance was predicted by their job satisfaction. Chamundeswari [16] examined job satisfaction and performance of 588 teachers chosen from central board schools, state board schools, and matriculation board schools. The study found a major difference in satisfaction and performance of teachers. According to the study, teachers in central board schools are knowingly more satisfied and, as a result, their job performance is also better than those teachers working in state and matriculation board schools.

Afshar and Doosti [17] investigated the influence of job satisfaction/dissatisfaction on the performance of Iranian English Teachers. Using 64 Iranian English Teachers and 1774 students as samples, the study found a difference between satisfied and dissatisfied teachers in terms of their performance, suggesting that the perceived dissimilarities in job performance might have been mainly caused by the degree to which they were satisfied with their profession. The study also found an important difference between students' evaluation and teachers' self-evaluation of the Iranian English Teachers performance

Mbaya [18] explored the influence of job satisfaction on public secondary school teachers' performance of Nairobi County. Using a total number of 92 school principals and teachers as samples, the study found a significant effect of the level of job satisfaction on public secondary school teachers' job performance. The opportunity for professional development and high remuneration are two constitutive factors for teachers' job satisfaction. The study finally concluded that salary, professional growth, working conditions, and recognitions affect much the level of job satisfaction and, in turn, encourage teachers to work harder than what are required.

Kyara [19] utilized a descriptive research design to investigate the impact of job satisfaction on primary school teachers' work performance in Kinondoni district. Using a total sample of 140 respondents, the study revealed the lowest level of job satisfaction in terms of school supervision, communication feedback, the availability of teaching-learning materials, school-parents relationship, on job training opportunities, promotion opportunities, salary, and the availability of transportation facilities. On the impact of job satisfaction on primary school teachers' job performance, the study revealed that low level of job satisfaction may impact negatively on primary school teachers' performance, absenteeism, and retention.

Funmilola, Sola, and Olusola [20] conducted a study to describe the effect of job satisfaction dimensions on job performance in a small and medium enterprise in Ibadan, Southwestern, Nigeria. Using a total number of 105 enterprise as samples, the study found that pay effects significantly on job satisfaction and performance especially when employees feel that pay schemes are seen as just, clear, and link with their hopes. The study also found that the quality of supervisor-subordinate relationships effects significant positively on the employees' satisfaction and performance. The study also found that the on job training and promotion opportunities will exert an effect on employees' satisfaction and performance. In other words, when the opportunities are given to employess to be promoted and to anvance their knowledge and skills, it will enhance employees' job satisfaction and performance.

Talabi [21] conducted a study investigating public secondary school teachers' satisfaction and work performance. Using 200 public secondary school teachers of Akoko Nort West Local Government Area of Ondo State as samples, the study concluded that teachers' job satisfaction relates significant positively to their work performace. The study found that variables such as pay packages, promotion opportunities, recognition, qualification, and the host of others influence much on job satisfaction and work performance of teachers. Since job satisfaction and work performance of public secondary school teachers of Akoko North West Local Government Area of Ondo State is significantly related, the study implied that if teachers' need not met by way of motivation or incentives, this may result in feeling of apathy, frustration, and inefficiency.

Hockwarter, Perrewé, Ferris, and Brymer [22] conducted a study investigating managerial personnels' satisfaction and performance. Using 270 managerial personnel of national hotel chains located across the United States as samples of the study, the result of the study found that job satisfaction and performance of managerial personnel would only demonstrate the strongest positive relationship when value attainment is 
coupled with either high or low affective disposition. At the end of the study, researchers encourage readers to view work as a complex phenomenon when piloting future research.

Pilarta [23] conducted a study to investigate whether teachers' satisfaction, teachers' performance, and students' academic achievement are significant positively related. Using 80 teachers and 1500 students as respondents, the study found that job satisfaction and performance of teachers are significant positively related in terms of predictors. On the job satisfaction, most of teachers are reported satisfied with their job status, achievement, personal relationship, promotion opportunity, and professional growth, but are not satisfied with the recognition and supervision. At the end of the study, researcher conluded that teachers' job satisfaction and their work success are significant positively related in terms of students' academic achievement and teachers' job performance.

\section{RESEARCH METHOD}

This study was quantitative in nature using a survey design as it provides the following six benefits: (a) high representation, (b) low cost, (c) convenient data gathering, (d) good statistical significant, (e) little researcher subjectivity, and (f) precise result [24]. We employed the survey as it pursued to describe job satisfaction of elementary school teachers of Boven Digoel district, Papua, and how it predicts their job performance.

Data of teachers' job performance were gathered by utilizing 15 items of questionnaire from a research piloted by Wea, Werang, Asmaningrum, and Irianto [25]. An Indonesian language version of the questionnaire was self-administered to the total number of 352 primary school teachers who have incidentally been established as respondents. Each teacher-respondent was asked to rate his/her own performance on a four point of Likert's scale as follows: 'strongly disagree' (SD) will be scored 1, 'disagree' (D) will be scored 2, 'agree' (A) will be scored 3, and 'strongly agree' (SA) will be scored 4. Sample of the English version of items are follows: "I help students improve their learning process and class improvement", "I prepare teaching materials at the beginning of the school year", "I evaluate students work diligently", "I personally provide learning media which are not provided by the school", "I use diverse learning media to teach for understanding", "I use diverse learning method and strategies to teach for understanding", "Ialways take an opportunity to participate in education conferences or seminars to upgrade knowledge and skills", and "I give chance for students to lead the class-discussion".

While the data of teachers' job satisfaction were gathered by utilizing 18 items of questionnaire from a research piloted by Werang and Agung [26]. An Indonesian language version of the questionnaire was self-administered to the total number of 352 primary school teachers who have incidentally been established as respondents. Each teacher-respondent was asked to rate his/her own satisfaction on a four point of Likert's scale as follows: 'strongly disagree' (SD) will be scored 1, 'disagree' (D) will be scored 2, 'agree' (A) will be scored 3, and 'strongly agree' (SA) will be scored 4. Sample of the English version of items are follows: "I feel I am being paid a fair amount for the work I do", "My supervisor is competent in doing his/her job", "When I do a good job, I receive the recognition for it that should I receive", "I like the people I work with", "The benefits I receive are as good as most other organizations", "Communications seem good with this organization", "Those who do well on the job stand a fair chance of being promoted", "I like doing the things I do at work", "The goals of this organization are clearly defined", "I feel a sense of pride in doing my job", "I am satisfied with my chances for promotion", "My job is enjoyable".

Research data were statistically analyzed using the simple linear regression analysis technique by employing the Statistical Package for the Social Sciences (SPSS) version 21. As this study was meant to describe job satisfaction of elementary school teachers of Boven Digoel district, Papua, and how it predicts their job performance, we offered one research hypothesis $\left(\mathrm{H}_{\mathrm{a}}\right)$ to be examined, that is job performance of elementary school teachers of Boven Digoel district, Papua, will be significant positively predicted by their job satisfaction. While the null hypothesis $\left(\mathrm{H}_{0}\right)$ is that job performance of elementary school teachers of Boven Digoel district, Papua, will be significant negatively predicted by their job satisfaction.

\section{RESULTS AND ANALYSIS}

Teachers are of the most important resources of any educational organization (school). In order to compete successfully in the global market and achieve its goals, school leaders and educational administrators at the government level as well should make sure that all the teachers are ready to work hard to move schools into its goals. This study attempted to describe the job satisfaction of elementary school teachers of Boven Digoel district, Papua, and how it predicts their job performance. As aforementioned, the effect between these two variables was examined using the simple linear regression analysis technique by employing the Statistical Package for the Social Science (SPSS) version 21. The significant effect is showed in Table 1. 
Table 1. The effect of job satisfaction on job performance

\begin{tabular}{|c|c|c|c|c|c|c|c|c|c|}
\hline \multirow{3}{*}{ Model } & \multicolumn{8}{|c|}{ Model Summary } & \multirow[b]{3}{*}{ Sig. F Change } \\
\hline & $\mathrm{R}$ & $\mathrm{R}$ & Adjusted & Std. Error of the & \multicolumn{4}{|c|}{ Change Statistics } & \\
\hline & & Square & R Square & Estimate & $\begin{array}{l}\text { R Square } \\
\text { Change }\end{array}$ & F Change & df1 & df 2 & \\
\hline 1 & $.266^{\mathrm{a}}$ & .071 & .068 & 4.83679 & .071 & 26.571 & 1 & 350 & .000 \\
\hline $\begin{array}{l}\text { Pr } \\
\text { De }\end{array}$ & $\begin{array}{l}\text { ctors: ( } \\
\text { ndent }\end{array}$ & $\begin{array}{l}\text { onstant), } \\
\text { ariable: } \mathrm{J}\end{array}$ & b_Performan & & & & & & \\
\hline
\end{tabular}

Table 1 displays that job performance of elementary school teachers of Boven Digoel district, Papua, was significant positively predicted by their job satisfaction as it was indicated by the coefficient value of $\mathrm{R}^{2}$ $=.071$ and the significant value is .000 . It inferred that at the level of alpha $(\alpha)=.05$, the research hypothesis $\left(\mathrm{H}_{\mathrm{a}}\right)$ that job performance of elementary school teachers of Boven Digoel district, Papua, will be significant positively predicted by their job satisfaction is confirmed, while the null hypothesis $\left(\mathrm{H}_{0}\right)$ that job performance of elementary school teachers of Boven Digoel district, Papua, will be significant negatively predicted by their job satisfaction is rejected.

Teachers' high performance will be achieved when their expectations and the goals of school are met. Regardless of what causes the state of dissatisfaction, Werang, Leba, and Pure [4] and Werang, Agung, and Hurit [5] reported that such dissatisfaction can lead to teacher counterproductive behavior such as heading for urban area for a long period of time or engaging with other attracted activities. Keeping on the view of teachers' capability in shaping their job satisfaction, a huge number of studies (e.g. [27-29]) suggest that principal leadership is the key factor in shaping teachers' attitudes toward their work. School principals behaviors such as making effort of fulfilling school goals, working hard and supporting teachers are likely to enhance teachers' job satisfaction and, in turn, to increase teachers' willingness to continue working in their respective schools [30]. Teachers need principal support to stay motivated and relaxed when facing workload, discipline issues, and social pressures [31]. Sympathetic school principals increases teachers' job satisfaction by encouraging teachers to participate actively in the process of school decision making, attending professional development, assisting teachers with discipline issues, arranging workshops for teachers, designing trust and collaboration among teachers $[32,33]$.

Besides, expanded decentralization of Indonesian educational framework has displayed the issue of local authorities' role and other intermediate bodies between the central government and the school as well as the role of school committees or other bodies involved in governing schools. The existence of such governing bodies result in the necessity of having school principals who are capable to negotiate with various powers and stakeholders [32]. Regardless the brilliant effort that have been made by the central government to fit school principals with all the competences needed, regional authorities' policy of assigning school principals based on their political interest makes it harder for teachers to have a school principal who "serve them as guardians in instructional time, assist them with student discipline matters, allow them to develop discipline codes, support their authority in enforcing policy" [34] and treat them as people "who have a multiplicity of needs, physical, emotional, and spiritual" [35].

The statistical result of this study $\left(\mathrm{R}^{2}=.071\right)$ demonstrates that for every point rising at the independent variable 'job satisfaction' will increase 0.71 point at the dependent variable 'job performance' and vice versa. It means that teachers' will grow more productive and are more likely to produce more than what are required from them when they are satisfied. Conversely, teachers will grow unproductive and are more likely to produce less than what are required from them when they are dissatisfied. The more teachers are satisfied, the better their performance; the more teachers are dissatisfied, the worst their performance. Finding of this study is in line with Collie, Shapka, and Perry's [36], Demirtas' [37], Griva, Panitsidou, and Chostelidou's [38] findings that teachers' with high level of satisfaction are more likely to provide higher quality teaching that benefits students' academic achievement. Finding of this study supports Ostroff's [39] findings that teachers with high level of satisfaction and of motivation tend to be more attracted in professional improvement, which subsequently can develop the quality of teaching.

Comparing to the results of previous studies as it was aforementioned, the statistical result of this study is categorized low because only $7.1 \%$ of the performance of elementary school teachers of Boven Digoel district, Papua, is predicted by their job satisfaction, while the remaining $92,9 \%$ is predicted by other variables. It means that there are still numorous predicting variables for the performance of elementary school teachers of Boven Digoel district, Papua, which need to be explored more in future studies. Despite the result of this study is similar enough to the previous ones, but as this report offers a first look on teachers' job satisfaction and performance in the context of elementary schools of Boven Digoel district, Papua, finding of this study may hypothetically contribute to the existing body of knowledge by providing valuable extension of relevant studies conducted in other countries. 


\section{CONCLUSION}

As this study offers a closer look on the job satisfaction of elementary school teachers of Boven Digoel district, Papua, and how it predicts their job performance, conclusion depicted from the result of data analysis is that the performance of elementary school teachers of Boven Digoel district, Papua, is significant positively predicted by their job satisfaction as it was indicated by the $\mathrm{R}^{2}$ coefficient value of .071 and the significant (Sig.) value of .000. It inferred that $7.1 \%$ of the performance of elementary school teachers of Boven Digoel district can be attributed to their job satisfaction. The remaining $92.9 \%$ can be attributed to other factors.

Because teachers' life is committed to the growth of the youth and their teaching work is not confined to the classroom, findings of this study may be imperative for educational administrator to make an effort of designing program to enhance teacher's job satisfaction in order to promote a better performance of elementary school teachers of Boven Digoel district, Papua. Besides, as this study offers a valuable information on the job satisfaction of elementary school teachers of Boven Digoel district, Papua, and it predicts their performance, finding of this study may hypothetically contribute to the existing body of knowledge on the job satisfaction and performance which have been investigated in other countries. Since this study is restricted on research factors and territory, a future research on teachers' job performance with a great number of factors (such as workload, individual characteristics, stress, morale, school leader) and a wider range of territory is highly suggested in order to have a better perspective on the phenomenon and to generalize the finding.

\section{ACKNOWLEDGEMENTS}

This manuscript would have never completed without the assistance of sponsors, teachers, and loved ones. Therefore, we would like to offer our great gratitude to the sponsors and teachers who have contributed much to the research. We wish to acknowledge our loved ones for their constant love and encouragement. We do hope this manuscript will benefit all the interested parties.

\section{REFERENCES}

[1] A. K. Vesely, D. H. Saklofske and A. D. W. Leschied, "Teachers-the vital resource: The contribution of emotional intelligence to teacher efficacy and well-being," Canadian Journal of School Psychology, vol. 28(1), pp. 71-89, 2013.

[2] M. J. Elias and H. A. Arnold, The educator's guide to emotional intelligence and academic achievement: social emotional learning in the classroom, Thousand Oaks, CA: Corwin Press, 2006.

[3] M. Alrajhi, S. Aldhafri, H. Alkharusi, S. Albusaidi, B. Alkharusi and A. Ambusaidi, "The predictive effects of math teacher emotional intelligence on their perceived self-efficacy beliefs," Teaching and Teacher Education, vol. 67, pp. 378-388, 2017.

[4] B. R. Werang, S. M.R. Leba and E. A. G. Pure, "Factors influencing teacher absenteeism in the remote elementary schools of Indonesia: Empirical proof from Southern Papua," International Journal of Management in Education, vol. 11(3), pp. 223-247, 2017.

[5] B. R. Werang, A. A. G. Agung and A. A. Hurit, "Increasing teacher attendance in Indonesia: A longitudinal study in the remote elementary schools of Southern Papua," International Journal of Management in Education, vol. 13(2), pp. 133-55, 2019.

[6] N. Selamat, N. Z. Samsu, and N. S. M. Kamalu, "The impact of organizational climate on teachers' job performance," Educational Research Journal, vol. 2(1), pp. 71-82, 2013.

[7] S. M. B. A. Zefeiti, N. A. Mohamad, "The influence of organizational commitment on omani public employees' work performance," International Review of Management and Marketing, vol. 7(2), pp. 151-160, 2017.

[8] M. S. Maningu, "The effect of teachers' morale in improving academic performance of secondary schools in Bukabo Municipal," Doctoral Thesis Presented to the Department of Administration Planning and Policy Studies of the Open University of Tanzania, 2017. [Online], Available: http://repository.out.ac.tz/1976/1/ MONICA\%20FINAL\%2000.pdf, [Accessed on December 8, 2018].

[9] S. Radja, C. Madhavi, and S. Sankar, "Influence of organizational climate on employee performance in manufactoring industry," Suraj Punj Journal for Multidisciplinary Research, vol. 9(3), pp. 146-157, 2019.

[10] S. Bhat, "Influence of organizational climate on job performance of teaching professionals: An empirical study," International Journal of Education and Management Studies, vol. 6(4), pp. 445-448, 2016.

[11] I. U. Khan and A. Nawaz, "The leadership styles and the employees performance: A review," Gomal University Journal of Research, vol. 32(2), pp. 144-150, 2016.

[12] S. B. Murali, A. Basit, and Z. Hassan, "Impact of job stress on employee performance," International Journal of Accounting and Business Management, vol. 5(2), pp. 13-33, 2017.

[13] O.M. Alade, O. O. Kuku, and A. Osoba, "Factors influencing candidates' performance in English Language and mathematics at West African Senior School certificate examination," International Journal of Evaluation and Research in Education, vol. 6(3), pp. 243-251, 2017.

[14] H. Ahmad, K. Ahmad, and I. A. Shah, "Relationship between job satisfaction, job performance, attitudes towards work and organizational commitment," European Journal of Social Sciences, vol. 18(2), pp. 257-267, 2013. 
[15] A. Rezaee, H. Khoshsima, E. Zare-Bahtash and A. Sarani, "A mix method study of the relationship between EFL teachers' job satisfaction and job performance in Iran," International Journal of Instruction, vol. 11(4), pp. 391-408, 2018.

[16] S. Chamundeswari, "Job satisfaction and performance of school teachers," International Journal of Academic Research in Business and Social Sciences, vol. 3(5), pp. 420-428, 2013.

[17] H. S. Afshar and M. Doosti, "Investigating the impact of job satisfaction/dissatisfaction on Iranian English teachers' job performance," Iranian Journal of Language Teaching Research, vol. 4(1), pp. 97-115, 2016.

[18] M. I. Mbaya, "The influence of job satisfaction on performance of teachers in public secondary schools in Nairobi County," MBA Thesis Presented to the School of Business, University of Nairobi. 2013. [Online], Available: erepository.uonbi.ac.kel.../Mghanga_The\%20influence \%20..., [Accessed on Dec 8, 2018].

[19] T. E. Kyara, "The effect of primary school teachers' job satisfaction on their work performance in Kinondoni District, Tanzania," M. Ed. Thesis Presented to the Open University of Tanzania, 2013. [Online], Available: repository.out.ac.tz/../I/THERESIA_EVARIST_KYARA.pdf. [Accessed Sep 8, 2018].

[20] O. F. Funmilola, K. T. Sola, and A. G. Olusola, "Impact of job satisfaction dimensions on job performance in a small and medium enterprise in Ibadan, South Western Nigeria," Interdisciplinary Journal of Contemporary Research in Business, vol. 4(11), pp. 509-521, 2013.

[21] A. S. Talabi, "Job satisfaction and work performance of public secondary school teachers in Akoko North West Local Government Area of Ondo State," Journal of Arts and Humanities, vol. 5(8), pp. 39-49, 2016.

[22] W. A. Hockwarter, P. L. Perrewé, G. R. Ferris, and R. A. Brymer, "Job satisfaction and performance: the moderating effects of value attainment and affective disposition," Journal of Vocational Behavior, vol. 54, pp. 296-313, 1999.

[23] M.A. B. Pilarta, "job satisfaction and teachers' performance in Abra State Institute of Sciences and Technology," Global Journal of Management and Business Research, vol. 15(4), pp. 81-85, 2015.

[24] B. R. Werang, "The effect of workload, individual characteristics, and school climate on teachers' emotional exhaustion in elementary schools of Papua," Cakrawala Pendidikan, vol. 37(3), pp. 457-469, 2018.

[25] D. Wea, B. R. Werang, H. P. Asmaningrum, and O. Irianto, "Teachers' working conditions and job performance in the elementary schools of Indonesia: A survey from Southern Papua," The International Journal of Educational Organization and Leadership, in print.

[26] B. R. Werang and A. A. G. Agung, "Teachers' job satisfaction, organizational commitment, and performance in Indonesia: A study from Merauke District," International Journal of Development and Sustainability 6 (8): vol. 6(8), pp. 700-711, 2017.

[27] K. M. Brown and S. R. Wynn, "Finding, supporting, and keeping: The role of the principal in teacher retention issues," Leadership and Policy in Schools, vol. 8(1), pp. 37-63, 2009.

[28] S. M. Johnson and S. E. Birkeland, "Pursuing a 'sense of success': New teachers explain their career decisions," American Educational Research Journal, vol. 40(3), pp. 581-617, 2003a.

[29] S. M. Johnson and S. E. Birkeland, "The schools that teachers choose," Educational Leadership, vol. 60(8), pp. 20-24, 2003b.

[30] F. K. Şemin, "Competencies of principals in ensuring sustainability education: teachers' views," International Journal of Evaluation and Research in Education, vol. 8(2), pp. 201-2012, 2019.

[31] Skolverket, Improving school leadership: background report Sweden. Swedish National Agency for School Improvement, 2007. [Online], Available: https://www.oecd.org/sweden/38613828.pdf, [Accessed Dec 8, 2018].

[32] A. Dorozynska, Teacher job satisfaction in primary schools: The relation to work environment, 2017. [Online], Available: https://gupea.ub.gu.se/bitstream/2077/51390/1/gupea_2077_51390_1.pdf, [Accessed Dec 8, 2018].

[33] B. R. Werang, "A study of relationships in Christian Primary Schools of Boven Digoel Regency, Papua, Indonesia," The International Journal of Educational Organization and Leadership, vol. 22(2), pp. 25-32, 2015.

[37] B. Mulford, "School leaders: Challenging roles and impact on teacher and school effectiveness," OECD Commissioned Paper, 2003. [Online], Available: www.oecd.org/education/school/37133393.pdf, [Accessed Sep 8, 2018].

[35] M. Rafferty, "The effect of teacher morale on teacher turnover rate," Ph.D. Dissertation Presented to Sam Houston State University, Huntsville, TX, USA, 2002. [Online], Available: http:// webb.nmu.edu/Webb/ArchivedHTML/ UPCED/mentoring/ docs/TeacherMorale.pdf, [Accessed Dec 8, 2018].

[36] R. J. Collie, J. D. Shapka and N. E. Perry, "School climate and social-emotional learning: Predicting teacher stress, job satisfaction, and teaching efficacy," Journal of Educational Psychology, vol. 104(4), pp. 1189-1204, 2012.

[37] Z. Demirtas, "Teachers' job satisfaction level," Procedia - Social and Behavioral Sciences, vol. 9, pp. 1069-1073, 2010.

[38] E. Griva, E. Panitsidou and D. Chostelidou, "Identifying factors of job motivation and satisfaction of foreign language teachers: Research project design," Procedia-Social and Behavioral Sciences, vol. 46, pp. 543-547, 2012.

[39] C. Ostroff, "The relationship between satisfaction, attitudes, and performance: An organizational level analysis," Journal of Applied Psychology, vol. 77(6), pp. 963-974, 1992. 